\title{
Is Improving Service Quality in Higher Education Satisfies Students? An Answer from Australia
}

\author{
Dr Gian Luca Casali and Erica French
}

\begin{abstract}
Assurance of learning is a predominant feature in both quality enhancement and guarantee of learning within Higher Education. It involves making program expectations and standards explicit, then systematically gathering and interpreting evidence to determine how well student performance matches those expectations. This benefits the institution by ensuring program aims are evaluated and used for program development, and is important for external scrutiny. It is common for Higher Degree institutions to concentrate on ensuring that their programs satisfy internal procedures and external rules and regulations. However, what this industry is currently lacking is taking into consideration the students' opinions. This project sought to investigate the student perceptions of the undergraduate and postgraduate program goals in one Australian Business School. A survey was used to gather student insights and values related to the goals of the programs and their experiences within the learning activities. Results indicate that while a significant number of students valued their program and recognized the assurance of learning goals and the means of achieving them, there were suggestions for greater learning outcomes and preparation for work.
\end{abstract}

Keywords - Assurance of Learning goals, Students' satisfaction, undergraduate and postgraduate education, Business Students

\section{INTRODUCTION}

Assurance of learning is an important process in educational settings as it allows for the evaluation of how well a program accomplishes the educational aims at the core of its activities, whilst assisting the faculty members to improve courses that constitute the program. Universities use the assurance of learning process to provide both qualitative and quantitative indicators of performance of teaching and learning for use in the assessment of the quality of award courses (Chalmers, 2008). These indicators of performance are used to guide the strategic directions, priorities, quality assurance and enhancement processes for teaching and learning. However, student participation is often ignored and until recently, student engagement data has been lacking regarding effective educational practices (Coates, 2010). Importantly, teachers' perspectives and expectations of a curriculum maybe different

Dr Gian Luca Casali, Associate Professor, Queensland University of Technology Brisbane Australia

Erica French, Associate Professor, Queensland University of Technology Brisbane Australia from what students perceive and experience regarding their development of graduate attributes (Bath, 2004). This study seeks to address this lack of knowledge and potential misalignment by asking the students about their opinions of the program goals and their perception of the values and the utilisation of these within units in the undergraduate and postgraduate masters program.

\section{LITERATURE REVIEW}

Graduate outcomes have been determined to include the knowledge outcomes pertaining to a program of study and the generic outcomes; commonly known as graduate attributes (Oliver 2011) and sometimes referred to as 'soft skills' or generic skills (Sykes et al. 2010). Graduate attributes have been defined as the 'descriptions of the core abilities and values a university community agrees all its graduates should develop as a result of successfully completing their university studies' (Barrie, Hughes, and Smith 2009, 1). The Australian Quality Framework describes graduate attributes as 'generic learning outcomes' and says these are transferable; nondiscipline specific skills a graduate may achieve through learning that have application in study, work and life contexts.

The value of understanding student perceptions of program goals is extensive to the current theory of graduate attributes and to the current practice of the Business School's assurance of learning process. Graduate attributes commonly reflect the professional capabilities of students and so they help learners to put their academic learning into a professional context, making the educational experience more authentic (Oliver and de St Jorre 2018). Graduate attributes are measured through intended learning objectives which are aligned to assessment tasks (Ashbaugh, Johnstone, and Warfield 2002). This means that students should be able to see the links and development of graduate attributes across a program through these clearly stated learning objectives, and through the aligned assessment. When learning objectives in assessments are designed to be well aligned and show development over time, students can take control of and progress in their learning through regular teacher feedback and self assessment. However if we do not understand the student perception of this process it may be an ineffective process. The benefit of this study is to unite our understandings of the theory of graduate attribute process with the students' perception of its value. Given the state of the 
literature the aim of this study twofold: Firstly to measure the relative and unique importance of twelve predictors of students overall level of satisfactions in both undergraduate and postgraduate university business students. Secondly to assess the potential conditional (i.e moderated) relationship between perceived development of personal skills and the overall level of satisfaction.

\section{METHODS \& RESULTS}

Research subjects were recruited via an introductory email sent to them (third year undergraduate and postgraduate university students enrolled in business programs) from a large university in Australia. Participants were provided with a link to an online questionnaire. A self-administered questionnaire was purposely developed to reflect the program learning goals and objectives across the degree programs in Business (De Vaus D.A. 2003). Twelve predictors were used in this study including statements purposively being developed to measure the different professional skills (Ammons, J., \& Mills, S. 2005) part of the assurance of learning goals (see Table $2 \&$ 3). Although these statements do not represent all the factors

TABLE I: DESCRIPTIVE STATISTICS

\begin{tabular}{|c|c|c|c|c|}
\hline & Undergraduate & Response total & Postgraduate & Response total \\
\hline \multicolumn{5}{|l|}{ GENDER } \\
\hline Male & $37.28 \%$ & 129 & $41.31 \%$ & 107 \\
\hline Female & $62.72 \%$ & 217 & $58.9 \%$ & 152 \\
\hline \multicolumn{5}{|l|}{ AGE } \\
\hline $17-20$ & $69.36 \%$ & 240 & $1.93 \%$ & 5 \\
\hline $21-30$ & $25.72 \%$ & 89 & $79.2 \%$ & 207 \\
\hline $31-40$ & $3.18 \%$ & 11 & $14.29 \%$ & 37 \\
\hline $41-50$ & $1.73 \%$ & 6 & $2.7 \%$ & 7 \\
\hline$>50$ & 0 & 0 & $1.16 \%$ & 3 \\
\hline \multicolumn{5}{|c|}{ STUDENT TYPE } \\
\hline Domestic & $37.28 \%$ & 129 & $31.66 \%$ & 82 \\
\hline Internationa & $62.72 \%$ & 217 & $68.34 \%$ & 177 \\
\hline \multicolumn{5}{|c|}{ STUDY MODE } \\
\hline Full Time & $92.2 \%$ & 319 & $82.63 \%$ & 214 \\
\hline Part time & $7.8 \%$ & 27 & $17.38 \%$ & 45 \\
\hline
\end{tabular}

The survey data was both imported into SPSS version 25 for statistical analysis and Nvivo for content analysis purpose. Initial descriptive and more complex statistical analysis has been performed on the data collected in order to provide a better understanding about the relationship between AOL goals and overall students' level of satisfaction with their university experience. The students do perceive their current studies prepare them well for a range of professional skills identified in the graduate attributes identified in The Faculty's undergraduate programs. that could influence students' overall levels of satisfaction, they well represent the main assurance of learning (AOL) goals in the business program within the assessed University representing those variables most likely to affect the students' learning experience and their university experience in general.

Student perceptions were captured via a forced choice on a Likert scale, 1-5, from very well (5) to very poorly (1), across a range of professional skills linked to the graduate attributes, and the level of satisfaction students perceived, as well as one open ended question related to how their educational experience could be improved. From the Faculty's total enrolment of 1,399 undergraduate students, a sample of 346 usable questionnaires was collected, providing a $27.6 \%$ response rate; and, from 800 postgraduate students a sample of 249 usable questionnaires was collected, providing a $31 \%$ response rate (See table 1). The undergraduate sample comprises $63 \%$ female and $37 \%$ male with almost $70 \%$ of the students being aged 20 years or less. The postgraduate sample is represented by $59 \%$ females and with almost $80 \%$ of the respondents between 21-30 years of age. 
TABle II: Undergraduate ThiRd Year StUdents' RESPONSES ABout DEgREe OF PREPARATION AOL

\begin{tabular}{|c|c|c|c|c|c|}
\hline $\begin{array}{l}\text { How well did your degree prepare you for a } \\
\text { professional situation that requires: }\end{array}$ & $\begin{array}{l}\text { Very } \\
\text { well }\end{array}$ & "Well & Neither & Poorly & $\begin{array}{l}\text { Very } \\
\text { poorly }\end{array}$ \\
\hline Teamwork skills & $14.7 \%$ & $62.0 \%$ & $16.3 \%$ & $4.7 \%$ & $2.3 \%$ \\
\hline Problems solving skills & 17.15 & $66.4 \%$ & $13.4 \%$ & $2.1 \%$ & $1.0 \%$ \\
\hline Leadership skills & $12.7 \%$ & $45.5 \%$ & $35.1 \%$ & $5.2 \%$ & $1.6 \%$ \\
\hline Time management skills & $29.7 \%$ & $46.8 \%$ & $19.1 \%$ & $3.9 \%$ & $0.5 \%$ \\
\hline Initiative and creativity skills & $14.0 \%$ & $44.4 \%$ & $32.3 \%$ & $7.2 \%$ & $2.1 \%$ \\
\hline Communication skills -Oral & 17.6 & $57.4 \%$ & 19.1 & $4.1 \%$ & $1.8 \%$ \\
\hline Communication skills- Written & $33.1 \%$ & $50.1 \%$ & $14.0 \%$ & $1.3 \%$ & $1.6 \%$ \\
\hline Ability to work independently & $43.2 \%$ & $45.2 \%$ & $10.3 \%$ & $0.8 \%$ & $0.5 \%$ \\
\hline Practical experience & $12.4 \%$ & $41.3 \%$ & $32.3 \%$ & $8.8 \%$ & $5.2 \%$ \\
\hline Ethical practice in your profession & $21.2 \%$ & $51.7 \%$ & $22.7 \%$ & $2.3 \%$ & $2.1 \%$ \\
\hline $\begin{array}{l}\text { Professional knowledge in your field } \\
\text { (accounting, HR, etc.) }\end{array}$ & $24.8 \%$ & $53.5 \%$ & $16.3 \%$ & $3.1 \%$ & $2.3 \%$ \\
\hline Intercultural awareness & $21.5 \%$ & $49.9 \%$ & $23.5 \%$ & $2.8 \%$ & $2.3 \%$ \\
\hline
\end{tabular}

TABle III: Postgraduate Students’ Responses about Degree of Preparation AOL

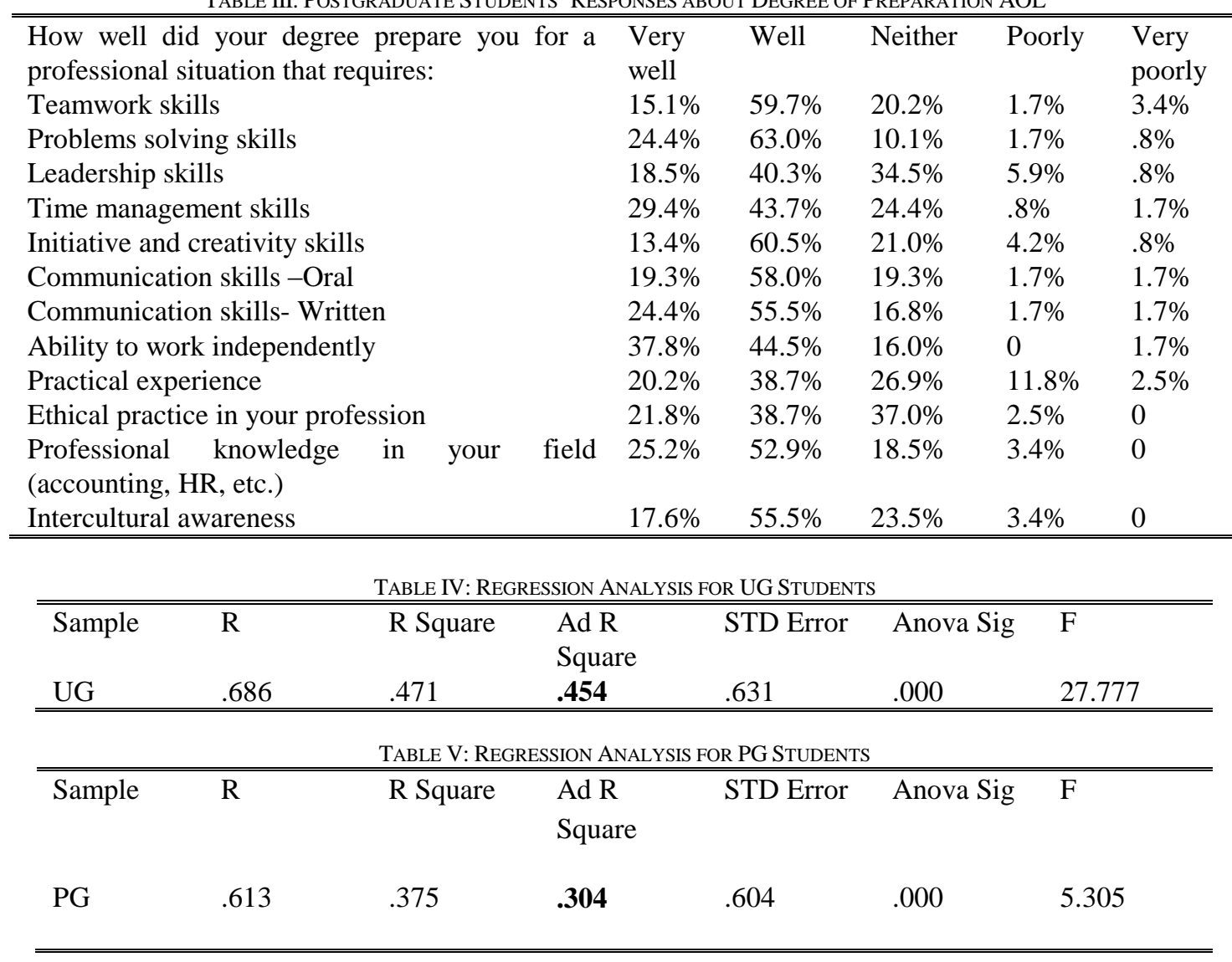

Results indicate that $45.4 \%$ of undergraduate students' and $30.4 \%$ of postgraduate students' level of satisfaction regarding their educational experience is explained by their perceived learning in terms of the different graduate skills identified and assured throughout the learning experiences in their program. Secondly a binary logistic regression was performed between the type of students (undergraduate and postgraduate) and the twelve different professional skills providing significantly (Omnibus tests of Model Sig .000 and Hosner \& Lemeshow
Sig .695), different results. This analysis was important to identify the potential difference between undergraduate and postgraduate based on the level that their degrees prepare them in relation to the graduate attributes. 
TABLE VI: LOGISTIC REgRESSION ON GRADUATE ATtRIBUTES AND STUDENT TYPE

\begin{tabular}{|c|c|c|c|c|c|c|c|c|}
\hline & B & S.E. & $\begin{array}{c}\text { Wal } \\
\mathrm{d}\end{array}$ & $\mathrm{df}$ & Sig. & $\begin{array}{c}\operatorname{Exp}(B \\
\quad)\end{array}$ & Lower & $\begin{array}{l}\text { Uppe } \\
\mathrm{r}\end{array}$ \\
\hline Teamwork skills & -.159 & .159 & $\begin{array}{r}1.00 \\
4\end{array}$ & 1 & .316 & .853 & .625 & 1.164 \\
\hline $\begin{array}{l}\text { Problem solving } \\
\text { skills }\end{array}$ & -.090 & .201 & .200 & 1 & .654 & .914 & .617 & 1.355 \\
\hline Leadership skills & .332 & .162 & $\begin{array}{r}4.18 \\
2\end{array}$ & 1 & .041 & 1.394 & 1.014 & 1.916 \\
\hline $\begin{array}{l}\text { Time } \\
\text { management skills }\end{array}$ & -.014 & .154 & .008 & 1 & .928 & .986 & .729 & 1.333 \\
\hline $\begin{array}{l}\text { Initiative and } \\
\text { creativity skills }\end{array}$ & -.311 & .161 & $\begin{array}{r}3.72 \\
4\end{array}$ & 1 & .054 & .733 & .534 & 1.005 \\
\hline $\begin{array}{l}\text { Communication } \\
\text { skills - oral }\end{array}$ & -.127 & .170 & .557 & 1 & .456 & .881 & .631 & 1.229 \\
\hline $\begin{array}{l}\text { Communication } \\
\text { skills - written }\end{array}$ & .793 & .176 & $\begin{array}{r}20.4 \\
16\end{array}$ & 1 & .000 & 2.210 & 1.567 & 3.118 \\
\hline $\begin{array}{l}\text { Ability to work } \\
\text { independently }\end{array}$ & -.140 & .179 & .614 & 1 & .433 & .869 & .612 & 1.234 \\
\hline $\begin{array}{l}\text { Practical } \\
\text { experience }\end{array}$ & -.672 & .141 & $\begin{array}{r}22.6 \\
65\end{array}$ & 1 & .000 & .511 & .387 & .674 \\
\hline $\begin{array}{l}\text { Ethical practice in } \\
\text { your profession }\end{array}$ & .147 & .157 & .880 & 1 & .348 & 1.159 & .852 & 1.576 \\
\hline $\begin{array}{l}\text { Professional } \\
\text { knowledge in } \\
\text { your field }\end{array}$ & .313 & .159 & $\begin{array}{r}3.88 \\
0\end{array}$ & 1 & .049 & 1.367 & 1.002 & 1.866 \\
\hline $\begin{array}{l}\text { Intercultural } \\
\text { awareness }\end{array}$ & -.198 & .153 & $\begin{array}{r}1.69 \\
3\end{array}$ & 1 & .193 & .820 & .608 & 1.106 \\
\hline Constant & -.146 & .412 & .125 & 1 & .724 & .865 & & \\
\hline
\end{tabular}

The main result of the binary regression is that there are clearly four graduate capabilities capable to significantly differentiate between undergraduate and postgraduate students (see table 6). Postgraduate students argued that their degree prepare them better in leadership, initiative \& creative skills and written communication skills. On the other hand, undergraduate students value more the contribution of professional knowledge in their programs.

In relation to the findings of the qualitative question: 'Please tell us how we can improve your educational experience?’ 240 students out of the overall sample of 506 made a comment which represents $47 \%$ of the students (figure 1). We used thematic content analysis to identify the major issues students identified for improvement in their student experience.

A number of specific areas of issues for change were identified through the thematic analysis: more practical experiences, structural changes and further communication (Table 7). Approximately forty per cent (40\%) of the students who commented, identified the desire for more real world experiences including internships; real case analyses; and, case study assessment and greater engagement with local firms. Second, the structural and process issues identified as requiring change included such suggestions as an increased number of units available on-line; less assessment and, less group work in assessment. Third, the students identified the need for greater interaction with them by the University in terms of social activities particularly for their first year experience. 


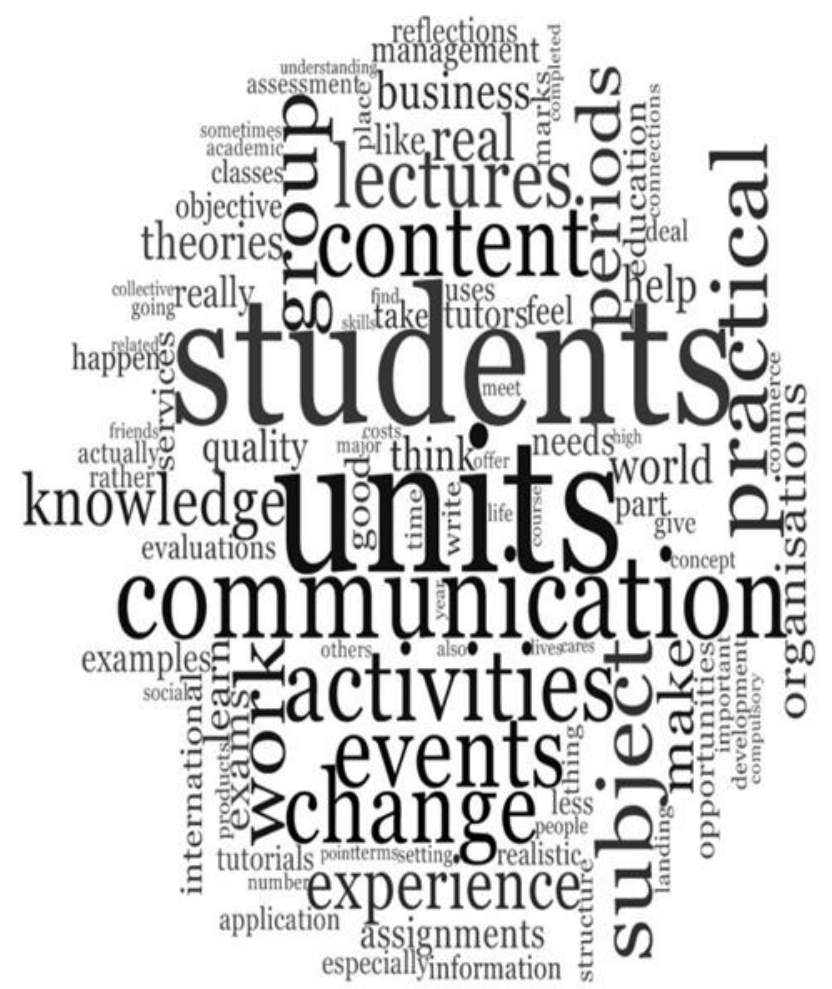

Fig. 1 Word Map based on Students' suggestions for improvements

TABLE VII: STUDENTS' COMMENTS FOR POSSIBLE IMPROVEMENTS

\begin{tabular}{lc}
\hline \hline Topic of the comment & Number \\
More real-world experience & 86 \\
Curriculum suggestions & 68 \\
Networking/Interaction & 34 \\
Other & 52 \\
Total comments & $\mathbf{2 4 0}$ \\
\hline \hline
\end{tabular}

\section{DISCUSSION}

Firstly, it is extremely important to highlight the fact that a clear relationship between students' overall satisfaction and their perceived level of learning about the different graduate skills exist. This is an important outcome as most previous research around the importance of graduate skills has been validated from an educational view (providers) but not from the end-users views (students). Furthermore, there is a clear difference between the importance of graduate skills for undergraduate and postgraduate students showing higher relevancy with undergraduate (see table $1 \& 2$ ). This could be explained by the significant age difference suggesting that $70 \%$ of undergraduate students are between the age of 17 and 20 years and $80 \%$ of the postgraduates are between 21 and 30 years. The age difference between the two cohorts of students could hide different levels of professional experience, suggesting that the younger cohort might have a much wider lack of experience and therefore be more in need of skills development than their counterparts. Furthermore, because of those salient demographical differences between the two cohorts is not unexpected that undergraduate students assess the contribution of professional knowledge Higher than their older (more experienced) counterpart. At the same time discovering that postgraduate students affiliate their level of satisfaction towards graduate capabilities such as leadership skills, Communication skills (written) and Professional knowledge is also in line with previous arguments. Finally, as a result of the qualitative question on the survey, the greatest number of students suggested the introduction of more practical learning to allow for more discipline related professional experiences. However, what is interesting in this study is what we did not find. Students discussed their greater access to professional experiences as the province of the 
institution rather than through their own self-directed participation and learning. It may be that higher education institutions need to promote more the concept of selfdevelopment; interactive learning and life-long learning, if this discipline and professional development is to be seen as a joint partnership between the student and the institution.

\section{REFERENCES}

[1] Ammons, J., \& Mills, S. 2005. Course-embedded assessments for evaluating cross-function integration and improving the teachinglearning process, Issues in Accounting Education, 20. (pp 1-19). https://doi.org/10.2308/iace.2005.20.1.1

[2] Ashbaugh, H., Johnstone, K., \& Warfield, T. 2002. Outcome assessment of a writing-skill improvement initiative: Results and methodological implications, Issues in Accounting Education. 17. (pp123-148). https://doi.org/10.2308/iace.2002.17.2.123

[3] Bath, D., C. Smith, S. Stein, and R. Swann. 2004. "Beyond Mapping and Embedding Graduate Attributes: Bringing Together Quality Assurance and Action Learning to Create a Validated and Living Curriculum." Higher Education Research \& Development 23 (3): $313-$ 328. https://doi.org/10.1080/0729436042000235427

[4] Chalmers, D. (2008, September). Teaching and learning quality indicators in Australian universities. Paper presented at the Institutional Management in Higher Education (IMHE) 2008 General Conference proceedings. $\quad$ Retrieved from http://www.oecd.org/dataoecd/4/40/41216416.pdf

[5] Coates H. 2010. Development of the Australasian survey of student engagement (AUSSE). Higher Education 60(1), 1-17 https://doi.org/10.1007/s10734-009-9281-2

[6] De Vaus D.A. 2003. Surveys in Social Research 5th ed. Marlborough VIC AUS: Allen and Unwin. https://doi.org/10.4135/9781446263495

[7] Barrie, S., C. Hughes, and C. Smith. 2009. The National Graduate Attributes Project: Integration and assessment of graduate attributes in curriculum. Australian Government, Office for Learning \& Teaching.

[8] Oliver B. and Jorre de St Jorre T. 2018, Graduate attributes for 2020 and beyond: recommendations for Australian higher education providers, Journal of higher Education Research \& Development 37(4) 821-836 https://doi.org/10.1080/07294360.2018.1446415

[9] Oliver, B. 2011. Assuring Graduate Outcomes. http://api.ning.com/files/Stx00vzPr3OLB02As1go2kjUu-cHkBe-

MYmmBh-

MjH9rqqKJZOwyOB62n0WuJr7hLe3EKAanIdua9xac0OJSWzFiqvqre $\mathrm{xBG}$ /AssuringgraduateoutcomesALTCGoodpracticereport.pdf.

[10] Sykes, C., M. Freeman, L. Simpson, and P. Hancock. 2010. "Improving Learning and Teaching through a Multi-Institutional, DisciplineSpecific Project.” Journal of Higher Education Policy and Management 32 (2): $173-184$.

https://doi.org/10.1080/13600800903575512 